International Journal of Life Sciences
Available online at http://sciencescholar.us/journal/index.php/ijls
Vol. 2 No. 3, December 2018, pages: 86 97
e-ISSN: 2550-6986, p-ISSN: 2550-6994
https://doi.org/10.29332/ijls.v2n3.209

\title{
Effect of Improvement on Work Attitudes and Work Environment on Decreasing Occupational Pain
}

\author{
I Ketut Widana a, Ni Wayan Sumetri ${ }^{b}$, I Ketut Sutapa ${ }^{c}$
}

Article history: Received 15 April 2018, Accepted: 30 August 2018, Published: 27 September 2018

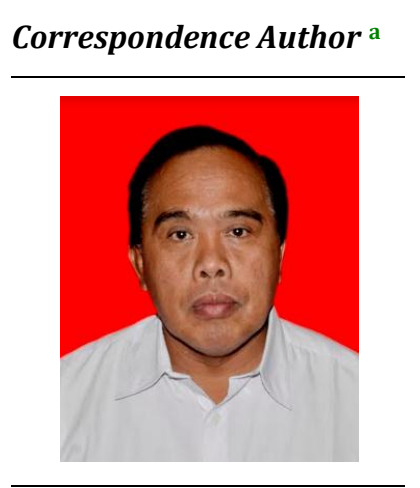

Keywords

Environment;

Ergo;

Fatigue

Mechanical;

Musculoskeletal;

\begin{abstract}
This research is an observation conducted on the health aspects of the work of carving artists, especially ergo-mechanical implementation to reduce subjective complaints. Ergo-mechanical is a set of equipment to maintain working environment conditions to remain within the required limits so that the carving artist remains in a safe and comfortable condition. This study begins with the direct observation of the process of carving handicrafts in several centers of carving crafts in Badung, Tabanan and Gianyar Districts. In accordance with the Bali State Polytechnic research master plan, problem-solving will focus on human aspects and the use of appropriate technology. This research method is experimental with the design of the same subject, involving 9 samples that carried out activities before and after treatment. Data on environmental conditions, fatigue, and musculoskeletal complaints are processed with statistics at a significance level of 5\%. The results showed that with ergomechanical implementation and ergonomic workstations, occupational health indicators such as musculoskeletal disorders and fatigue showed better data, characterized by decreased musculoskeletal disorders, and reduced fatigue.
\end{abstract}

e-ISSN: 2550-6986, p-ISSN: 2550-6994@C Copyright 2018. The Author. SS Journals Published by Universidad Técnica de Manabí. This is an open-access article under the CC BY-SA 4.0 license (https://creativecommons.org/licenses/by-sa/4.0/) All rights reserved.

\section{Contents}

Abstract

1. Introduction...

等

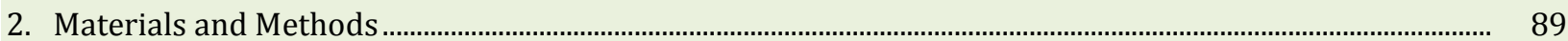

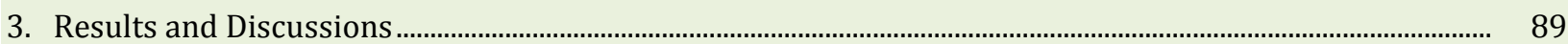

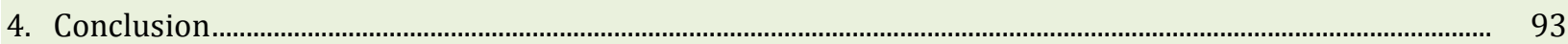

a Mechanical Engineering Department, Bali State Polytechnic, Badung, Indonesia

b Business Administration Department, Bali State Polytechnic, Badung, Indonesia

c Civil Engineering Department, Bali State Polytechnic, Badung, Indonesia 


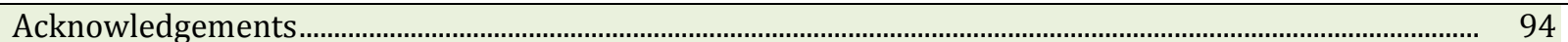

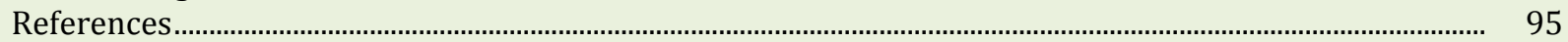

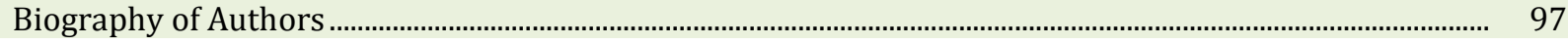

\section{Introduction}

Art sculpture has a long history in the country. The historical relics of the carvings represented by Borobudur Temple and Prambanan Temple and the latest Garuda Wisnu Kencana in Ungasan Badung show that the development of art is getting better from century to century. However, developments in art and architectural splendor were not matched by an adequate appreciation for carving artists. In contrast to painting which gives appreciation to artists, for example with adjustable seating and canvas, carving artists are very far behind. The position and work attitude of monotonous carving artists from time to time, bend and fold legs, with a work environment that is far from safe and comfortable. It is time for researchers to pay attention to the academic touch so that the carving artists can sit upright and comfortably on chairs with work pieces on the table in front of them.

Based on research by Epstein and Moran (2006) provides an explanation that supports the above statement, that fatigue, pain and even increased heart rate has a strong correlation with the work environment. A hot working environment can cause heat stress that spurs the heart rate. Under normal conditions, our heart will be pulsed 60 times per minute, but if the range is up to 125 - 150 beats $/ \mathrm{min}$, which includes weight classification, it can cause various health effects (Christensen, 1991). Fatigue is also not good if left to last for a long time. Tiredness is similar to a siren or warning light that indicates something is wrong in our body. Tiredness is actually the same as a crying baby, although it can not be guessed accurately, at least we can expect something to get handling, such as wet, hungry, thirsty or just want attention. From the aspect of production, the fatigue that we feel will cause the productivity of labor. Reference Bubb (2013), gives a plausible argument, that if the producer gives little attention to the human aspect of running the machine, then productivity will certainly increase soon. There is a psychological aspect that can explain the logic, that when tired all the desire for achievement will decrease.

Reference Bubb (2013), as in Epstein and Moran (2006) and Erensal and Albayrak (2007) also proved in his analysis that humans can be very productive if always in a fit state. Fit conditions are characterized by low levels of musculoskeletal or musculoskeletal disorders (MSd) during on-the-job activity. Musculoskeletal disorders can be reduced and even eliminated if humans in the move can still be in a natural position. Reference Hignett et al., (2005), found a sure-fire way to reduce pain in skeletal muscle (musculoskeletal) while working, that the size of the human body wearing a tool used to design the size of the work table and chairs, so that the worker's body position during the move permanent in a natural or scientific position. The results of this study are in line with the results of the analysis as in Chandna et al., (2010) which passes a survey on the industrial workforce in North India, which results in the conclusion that anthropometric work piece positions can eliminate work-related pain. By the various problems above, in the realm of art carving also experienced the same thing.

There is a common phenomenon that can be witnessed in the community that when carving artists will experience a variety of occupational health problems. There has been no serious effort from health circles that provide socialization and a way out of existing problems. Needed a helping hand academics to examine if it is possible the carving artist can move comfortably without disorders of skeletal muscles, fatigue is not too high. This research attempts to reduce pain, fatigue excess by making the body the artists remain on the attitude of its natural and supported by the comfortable environment, which is set up chairs and desks in accordance with the size of anthropometry artist and set the intensity of illumination, wind speed, noise, temperature and humidity of the room. Based on the preliminary study data, it is found that the shape and size are most closely approximated the anthropometric size for art carving workers. The issues raised in this research is how the workstation ergonomics can reduce musculoskeletal disorders and reduce the fatigue of the craftsmen as well as how the relationship between the variable musculoskeletal disorders and fatigue with work productivity of the craftsman, while purpose of the study is to change the paradigm long rigid and dogmatic, that "the sculptor's work sitting on the floor with his back bent" into a dynamic new paradigm, namely "the sculptor job fun because it can choose the position and attitude of a comfortable working in a place corresponding to the anthropometry of workers".

Widana, I. K., Sumetri, N. W., \& Sutapa, I. K. (2018). Effect of improvement on work attitudes and work environment on decreasing occupational pain. International Journal of Life Sciences, 2(3), 86-97. https://doi.org/10.29332/ijls.v2n3.209 
Bali has been inhabited by humans since antiquity. Past historical proofs include megalith sites in various shapes and sizes that can be seen both in museums and in the open. The relics of Balinese carving culture are the result of the creation of the sculpture of the ancestors, consisting of stone statues of human shape, animal, menhir, dolmen, punden staircase, stone grave, stone mortar and so on small to giant. The evidence of civilization in the period 2500-1000 years BC is not only impressive for foreign and domestic tourists, but also for experts who often come to do scientific research. The development of art in Bali is very rapid, thus attracting tourists to come to visit Bali. The arts that exist today include dance, carving, and painting. Carving art craft is much favored and in demand by foreign and domestic tourists so managed as a small or medium industry depending on the amount of capital and labor used. Carved art craft products many kinds ranging from eye cendra to carvings for buildings typical of Bali (Widana et al., 2018). Some of the problems associated with occupational health are skeletal muscle disorders and fatigue.

Based on research by Carrivick et al., (2002) explains that working anywhere is inseparable from the fatigue because in the process of working activity requires muscle and mental work simultaneously shown through the fatigue marked by the change in the frequency of the pulse. Furthermore as in Chaff'm (1974) says that according to the rules of ergonomics, every burden received by the body must be balanced with the physical and cognitive abilities as well as the limitations of the body that accepts the burden. The human body's ability to accept loads varies greatly, depending on skill level, fitness, nutritional intake, gender, age, and body anthropometry. The lightweight of an activity can be seen from the need for oxygen, the capacity of pulmonary ventilation, changes in core body temperature, energy requirements and the production of sweat or weight changes. Heart rate is a good estimator of metabolic rate, except in the emotional state and vasodilation (widening of blood vessels) (Alamgir et al., (2008), (Nishanth et al., 2015). The weight category of workload is based on metabolism, respiration, body temperature and heart rate (Christensen, 1991). According to McCann (2010), the energy for the body needs is the chemical energy contained in the carbonhydrogen bonds of food. This energy can not be used directly by the body and must take from food after being converted into high-energy phosphate bonds in Adenosine Tri-Phosphate (ATP). ATP requirements are highly dependent on the level of workload or type of work performed. ATP requirements will increase in increased workload.

The second problem related to occupational health is musculoskeletal disorders. Art workers in the move will experience physiological changes as a result of the accumulation of external and internal loads. Internal burdens such as body weight, mental burden, and health impairment also collectively affect workers, all of which can cause stress (Eastman, 1983). Stress received by the body is actively anticipated in the form of work and passive system efficiency in the form of physiological reactions known as adaptive responses. According to Mitchell (2013) and Epstein and Moran (2006), in conclusion, his research, that physiological changes aim to maintain cell metabolism in the optimal state. To achieve this necessary intake of oxygen and food substances continuously. In addition, muscle contraction and relaxation should be regular. When the energy supply is limited and the flow of oxygen and nutrients is disrupted then the cell metabolism will be disrupted thus accelerating the onset of musculoskeletal disorders. Workers who use workstations and workplaces that have dimensions that are less suited to the anthropometry of the worker will cause less unnatural movements and work attitudes, so musculoskeletal disorders will occur earlier and more severe. The musculoskeletal system is a muscular system attached to the bone composed of cross-shaped muscle fibers of voluntary movement (Carrivick et al., 2002). The third problem related to occupational health is fatigue. Fatigue consists of muscle fatigue and general fatigue. Muscle fatigue is a very painful symptom of pain when muscles suffer from excessive stress, while general fatigue is a stage marked by a decrease in readiness to use energy. As explored by Wilson and Morris (2005) or Habibi and Soury (2015) and Chaff'm (1974) suggest general symptoms of fatigue can start from very mild to exhausting feelings. Subjective fatigue usually occurs at the end of working hours, if the average workload exceeds $30 \%-40 \%$ of the maximum aerobic power. Fatigue usually indicates the different conditions of each individual, but it all leads to loss of efficiency and decreased work capacity and body resistance. Based on research by Grandjean (2000) and Bubb (2013) indicate fatigue in general is a condition that is reflected in symptoms of psychological changes in the inaction of motor activity and respiration, the presence of pain, weight on the eyeballs, attenuation of motivation, decreased activity that will affect physical and mental activity.

One obvious effect of fatigue is reduced alertness. A person will not be able to concentrate continuously for mental activity. After experiencing tension during a certain period, there will be a disturbance in perception, and the speed of the reaction becomes slow. To overcome this interference need to be refreshed outside of pressure (Eastman, 1983). Refreshes occur mainly during night time sleep or rest periods and during work breaks. It should gradually begin to be considered for the workstation to be moved on. Utilization of 
appropriate technology is one of the solutions offered (Caverley, 2005). Held a paradigm shift from conventional work stations working on the floor without regard to health change. Craftsmen are encouraged to start using tables and chairs to increase productivity, reduce workload, lower musculoskeletal and fatigue complaints.

Wind speed should be made not too tight and not too stagnant. With a blow of $\pm 4 \mathrm{~m} / \mathrm{min}$, the natural wind will be able to keep the worker's physical condition in shape throughout the day. Artificial lighting or lamp use should be able to make the worker work hard. With a light intensity of 300 lux or more can prevent art workers from accidents due to work or errors in determining the size of the chisel (Dutta et al., 2011; Kumar and Chakrabarti, 2013). Air humidity should be maintained in the range of $70 \%$ to $76 \%$ to allow perspiration to escape from the skin pores ${ }^{30}$. Noise should be avoided for carving workers because it can affect concentration and accelerate psychological fatigue. Air temperature will be better if it can be maintained in the range of $24^{\circ}$ Celsius to $28^{\circ}$ Celsius for better working comfort and worker satisfaction can be maintained (Widana, 2012; Parasuraman, 1988).

\section{Materials and Methods}

To know the impact of treatment/intervention on subject conditions was done experimental research with the same subject design (Treatment by subjects design). Based on the design, the measurement is done twice before and after the implementation of workstation and ergonomic environment. Ergo-echanical regulates workspace conditions by increasing wind speed and increasing light intensity. With increasing wind speed, temperature and relative humidity indicators will improve, as well as good light intensity, accuracy and productivity parameters will be increased

The tools used to retrieve data consist of : Japanese Olympus FE-15 digital camera for documentation, table of psychrometry to determine relative humidity by \% unit, sound level meter, lux meter, black globe thermometer, sling thermometer, anemometer, super Japanese anthropometry tool made in Japan with $0.1 \mathrm{~cm}$ accuracy, which was used to measure the anthropometry of the subject. Fatigue Questionnaire and Nordic Body Map questionnaire.

Data were collected from samples at industrial centres of carving stations in Tangeb Village and Kapal Village, namely UD. P. Jatayu, UD. Rinna Dewata Sari, UD. Agus. Selected samples were collected in Ud. Agus for treatment. The object of research was workstation and work environment of Bali carving artisans. While the questionnaire used is Nordic Body Map and 30 item of the rating scale. The environmental conditions were observed with a sound level meter, lux meter (for measuring the intensity of light), sling thermometer (measuring wet temperature and dry temperature), black globe thermometer (measuring radian temperature) and anemometer (to measure wind speed).

To avoid errors in data collection, then based on the identification and classification of variables, created operational definition variables. Musculoskeletal disorders are the pain felt by workers after activity. Fatigue, sleepiness, lack of concentration and bored perceived workers after activity. Ergonomic Work Station is a convenient workplace for activities. There are 2 aspects that are improved to reduce work-related pain. First, provide anthropometric chairs and tables. Both improve working environment conditions, such as adjusting the intensity of lighting, adjusting wind speed, limiting noise, regulating wet temperatures, adjusting dry temperatures and regulating moisture.

Subjects are carved artists who are voluntarily willing to participate in research. The task is a job or task that must be completed by a subject, either when not using ergonomic workstation or when already using ergonomic workstation. To reduce the errors of the research results due to differences in treatment of samples, equipment that may be used during the study is also maintained or controlled so that between subjects with one subject will get the same equipment when the move. Task loads will also be made equal, both the difficulty level and the volume of work.

\section{Results and Discussions}

Characteristics of subjects including age, weight, height, work experience, resting pulse and body mass index (BMI) are presented in Table 1.

Widana, I. K., Sumetri, N. W., \& Sutapa, I. K. (2018). Effect of improvement on work attitudes and work environment on decreasing occupational pain. International Journal of Life Sciences, 2(3), 86-97.

https://doi.org/10.29332/ijls.v2n3.209 
Table 1

Subject characteristics

\begin{tabular}{clccc}
\hline No. & \multicolumn{1}{c}{ Description } & Average & Standard of Deviation & Range \\
\hline 1 & Age (year) & 37,72 & 4,72 & $30-51$ \\
2 & Weight (kg) & 60,56 & 6,22 & $49-71$ \\
3 & Height (cm) & 167,61 & 4,12 & $150-171$ \\
4 & Work experience (year) & 11,31 & 4,91 & $10-20$ \\
5 & Resting pulse Period I (bpm) & 84,31 & 3,92 & $77,33-90,67$ \\
6 & Resting pulse Period II (bpm) & 78,02 & 4,53 & $69,33-85,33$ \\
7 & Body mass index (BMI) (kg/m2) & 21,67 & 3,37 & $18,34-24,89$ \\
\hline
\end{tabular}

Description $: \mathrm{bpm}=$ beats per minute

The number of the subject for research consisted of workers at Senior high school level (44.44\%), while those had elementary and college education are $33.33 \%$ and $22.22 \%$ respectively. Subjects totaling 9 people are all male and are employees at UD. Jatayu, CV. Rinna and UD. Agus. The lifespan of the subject is 30 to 51 years, average $37.72 \pm 4.72$. Subject weight ranges from 49 to $71 \mathrm{~kg}$ with a mean of $60.56 \pm 6.22 \mathrm{~kg}$. The subject's height is in the range of 150 to $171 \mathrm{~cm}$ with a mean of $167.61 \pm 4.12 \mathrm{~cm}$. The work experience of the subject as a farmer ranged from 10 to 20 years with an average of $11.31 \pm 4.91$ years. Work experience related to the ability of adaptation and freshness level of craftsmen.

The resting pulse can also show the degree of physical fitness of a person, the lower the resting pulse of a person the better the physical fitness. In this study, the subjects' pulse rate ranged from 77.33 to 90.67 beats per minute (bpm) with an average of $84.31 \pm 2.92 \mathrm{bpm}$ before the ergonomic implementation (study period I) and between 69.33 to $85.33 \mathrm{bpm}$ with a mean of $78.02 \pm 4.53$ beats per minute (bpm) after the implementation of ergonomics (research period II). The resting pulse in period I and period II is still in the range of $69.33 \mathrm{bpm}$ to $90.67 \mathrm{bpm}$, which shows the physical condition of the subject in good health, because the workload is very light to the light category.

Prior to the conduct of the study, all the population received medical examinations from the Doctors. Out of 45 people, 9 of them were selected. From the results of the examination which includes blood pressure measurement, sugar levels in time and pulse have obtained the health status of the sample, which is healthy. The result of normality test to the environmental condition data, both for the working environment condition during the period I and period II shows that normal distribution data is light intensity data, while dry temperature data, wet temperature, humidity, ball temperature, wind speed, noise, and WBGT index not normally distributed. If one of the data is not normal then the test using non-parametric test equipment. Thus the data were tested by Mann-Whitney test. The results of data analysis of environmental conditions in the workshop of the crafters can be seen in Table 2 .

Table 2

Environment condition

\begin{tabular}{lcccccc}
\hline \multirow{2}{*}{ Variable } & \multicolumn{2}{c}{ Period I } & \multicolumn{2}{c}{ Period II } & Value & Value \\
\cline { 2 - 7 } & Average & SD & Average & SD & Z & p \\
\hline Dry temperature $\left({ }^{\circ} \mathrm{C}\right)$ & 27.64 & 0.82 & 27.61 & 1.14 & -1.721 & 0.068 \\
Wet temperature $\left({ }^{\circ} \mathrm{C}\right)$ & 24.11 & 1.14 & 23.97 & 1.21 & -1.227 & 0.221 \\
Relative humadity $(\%)$ & 76.18 & 4.61 & 76.22 & 4.67 & -0.739 & 0.461 \\
WBGT index $\left({ }^{\circ} \mathrm{C}\right)$ & 25.17 & 1.11 & 25.12 & 1.10 & -1.366 & 0.171 \\
Wind speed $(\mathrm{m} / \mathrm{dt})$ & 11.15 & 3.02 & 11.07 & 2.82 & -1.112 & 0.487 \\
Light Intensity (lux) & 190.00 & 4.71 & 193.00 & 6.89 & -0.043 & 0.965 \\
Ball temperature $\left({ }^{\circ} \mathrm{C}\right)$ & 29.77 & 0.82 & 29.31 & 0.96 & -1.396 & 0.164 \\
Noise $(\mathrm{dBA})$ & 74.337 & 6.53 & 74.61 & 6.91 & -0.313 & 0.754 \\
\hline
\end{tabular}

Environmental conditions consisting of dry temperature, wet temperature, relative humidity, wind speed, light intensity, ball temperature, and noise also greatly affect the subject condition. The data of light intensity, wind speed and noise are measured at five points and at different times. The result of data analysis shows that 
environmental condition seen from dry temperature, wet temperature, ball temperature, relative humidity, wind speed, light intensity, and noise period I and in period II is no different. It is said that because all values p> 0.05 or it can be said that : (a) the average of dry temperature in the study period I is not significantly different with the average of dry temperature at the time of observation period II; (B) the average of wet temperature at observation period I was not significantly different with a mean wet temperature of period II; (C) the average of sphere temperature at observation period I was not significantly different with mean of ball temperature of period II; (D) the relative humidity average at observation period I was not significantly different with the mean of relative humidity during observation period II; (E) the average of wind velocity in observation of period I is not significantly different with mean of wind velocity of period II, and (f) average of noise, WBGT and light intensity at observation period I is not significantly different with mean of noise, WBGT and light intensity of period II.

To know the suitability between the tools used by artisans did anthropometry measurement. The size obtained should be in accordance with the size of the body and comfortable to use by crafters (Helander, 1995; Pheasant, 1991; Dul and Weerdmeester, 1993). Anthropometric data is very important for the designers of the tool to get the most appropriate size. The more samples involved the better, even in developed countries already available anthropometry data that represent the population of the country. Data obtained by (1) all subjects measured; (2) anthropometric data of all subjects is taken the average and its standard intersection (3) the average value of the subject then searched the percentile value with SPSS.

From anthropometry data of then desk and chair work in design, the height of the table uses a high reference point 95th elbow, so the table height is determined $71.7 \mathrm{~cm}$. Table length uses a 95th percentile shoulder width of 95 , which is $49 \mathrm{~cm}$, so the length of the table is made $100 \mathrm{~cm}$. Table width is determined using 95th percentile hand coverage range, so it is made $69 \mathrm{~cm}$. Musculoskeletal disorders data were obtained from the Nordic body map questionnaire using a 4-level Likert scale. The use of scale 4 is based on a relatively low level of sample education. The questionnaire has tested its reliability with the Cronbach alpha value of 0.475 . The value of $r$ arithmetic is above the $r$ table value. The $r$ table value for the 30 person subject is 0.2407 , at $95 \%$ confidence level or $5 \%$ significance level. If alpha is count $>r$ table and is positive then the instrument is reliable.

Before performing the test using a statistical test apparatus, the figures recorded in the study were tested by the normality test. Based on the normality test with Shapiro-Wilk obtained the results as in Table 3.

Table 3

Normality test data of musculoskeletal disorders

\begin{tabular}{clccc}
\hline No. & \multicolumn{1}{c}{ Description } & Value Z & Df & $\begin{array}{c}\text { Value } \\
\mathrm{p}\end{array}$ \\
\hline 1 & $\begin{array}{l}\text { Musculoskeletal Disorders } \\
\text { Period I pre-activity }\end{array}$ & 0.891 & 9 & 0.062 \\
2 & $\begin{array}{l}\text { Musculoskeletal Disorders } \\
\text { Period II pre-activity }\end{array}$ & 0.912 & 9 & 0.123 \\
3 & $\begin{array}{l}\text { Muskuloskeletal Disorders } \\
\text { Period I after activity } \\
\text { Musculoskeletal Disorders }\end{array}$ & 0.940 & 9 & 0.333 \\
Period II after activity & 0.941 & 9 & 0.352 \\
\hline
\end{tabular}

From Table 3 the value of $\mathrm{Z}$ musculoskeletal disorders in the period I before the activity was 0.891 with pvalue $=0.062$, likewise on the value of $\mathrm{Z}$ period II before the activity was 0.912 with $\mathrm{p}=0.123$. After activity $\mathrm{Z}$ value of musculoskeletal disorders in period, I was 0.940 with $\mathrm{p}$-value $=0.333$ and $\mathrm{Z}$ value of musculoskeletal disorders in period II was 0.941 with value $p=0.352$. The four data are normally distributed because of the $p>$ 0.05 .

Musculoskeletal disorders data before the activity need to be known to give confidence that the decrease of musculoskeletal disorders in period II is solely due to the activity carried out and not by the rest of the disorders in period I. If the data is comparable ( $p>0.05)$ then it can be said that the change Musculoskeletal disorders in the second period were caused only by the treatment effect. Due to the data is normally

Widana, I. K., Sumetri, N. W., \& Sutapa, I. K. (2018). Effect of improvement on work attitudes and work environment on decreasing occupational pain. International Journal of Life Sciences, 2(3), 86-97. https://doi.org/10.29332/ijls.v2n3.209 
distributed, then tested with the parametric test in the form of t-paired test. The results of the analysis can be seen in Table 4.

Table 4

Analysis of musculoskeletal disorders

\begin{tabular}{llrlccc}
\hline \multicolumn{1}{c}{ Variable } & \multicolumn{2}{c}{ Period I } & \multicolumn{2}{c}{ Period II } & Value & Value \\
& Average & SD & Average & SD & $t$ & $p$ \\
\hline $\begin{array}{l}\text { Musculoskeletal Dirorders Score pre- } \\
\text { activity }\end{array}$ & 32.34 & 0.95 & 32.22 & 0.87 & 1.648 & 0.121 \\
$\begin{array}{l}\text { Musculoskeletal Disorders Score after } \\
\text { activity }\end{array}$ & 54.61 & 3.56 & 46.19 & 2.36 & 26.873 & 0.0001 \\
\hline
\end{tabular}

From Table 4 the mean of musculoskeletal disorders after activity in period I was $54.61 \pm 3.56$ and mean of musculoskeletal disorders in period II after activity was $46.19 \pm 2.36$ with $\mathrm{t}$ value $=26.873$ and $\mathrm{p}$-value $=$ 0.0001. That means there is an average difference in musculoskeletal disorders between period I and period II.

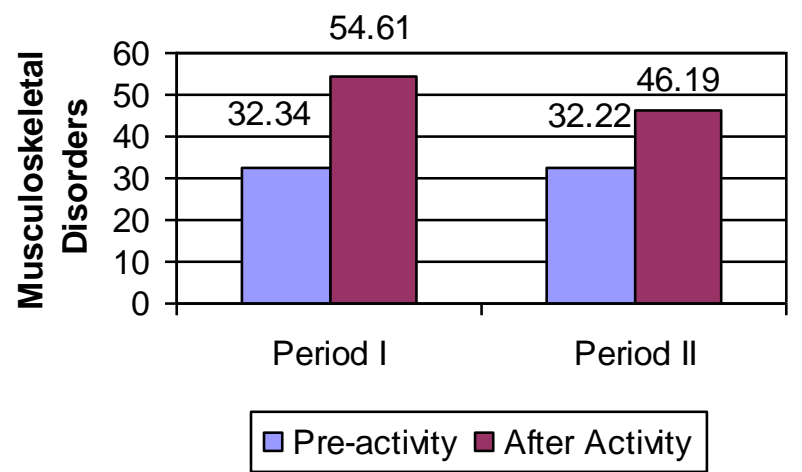

Figure 1. Musculoskeletal Disorders

Craftsman fatigue was tested by filling out a questionnaire of 30 items of rating scale before and after the activity. The results of normality data testing for fatigue can be seen in Table 5. Tiredness is not really a bad thing. With the appearance of fatigue is a warning for workers to immediately rest (Borg, 1990; Gilad, 1998; Sakurai, 2012). The $\mathrm{Z}$ value of fatigue data in period I before the activity was 0.888 with $\mathrm{p}$-value $=0.051$, similarly in period II before the activity was 0.696 with $\mathrm{p}=0.0001$. $\mathrm{Z}$ value of fatigue data period I after activity is 0.745 with value $p=0.001$ and in period II is 0.797 with value $p=0.003$. Thus it can be said that the data is not normally distributed.

Table 5

Data normality of fatigue

\begin{tabular}{ccccc}
\hline No. & \multicolumn{1}{c}{ Description } & Value Z & $D f$ & Value p \\
\hline 1 & $\begin{array}{l}\text { Fatigue of Period I } \\
\text { pre-activity }\end{array}$ & 0.888 & 9 & 0.051 \\
2 & $\begin{array}{l}\text { Fatigue of Period II } \\
\text { pre-activity }\end{array}$ & 0.696 & 9 & 0.0001 \\
3 & $\begin{array}{l}\text { Fatigue of Period I } \\
\text { after activity }\end{array}$ & 0.745 & 9 & 0.001 \\
4 & $\begin{array}{l}\text { Fatigue of Period II } \\
\text { after activity }\end{array}$ & 0.797 & 9 & 0.003 \\
\hline
\end{tabular}


The pre-activity fatigue both in period I and period II was also calculated to reinforce the results of the analysis that the occurrence of fatigue decline in the second period after activity was solely due to the influence of the treatment given. Because the data is not normally distributed then the test is done by Wilcoxon Signed Ranks Test. Based on the test results obtained such as analysis Table 6.

Table 6

Analysis of fatigue

\begin{tabular}{lcccccc}
\hline \multicolumn{1}{c}{ Variable } & \multicolumn{2}{c}{ Period I } & \multicolumn{2}{c}{ Period II } & Value & Value \\
& Average & SD & Average & SB & Z & P \\
\hline Fatigue Before Activity & 32.22 & 0.93 & 32.20 & 2.03 & -0.321 & 0.748 \\
Fatigue After Activity & 60.72 & 0.52 & 52.66 & 0.55 & -3.901 & 0.0001 \\
\hline
\end{tabular}

From Table 6, the mean of fatigue before activity in period I was $32.22 \pm 0.93$ and the mean of fatigue before activity in period II was $32.20 \pm 2.03$ with value $\mathrm{Z}-0.321$ and $\mathrm{p}$-value $>0.05$. This value indicates that the data do not differ significantly between period I and period II. That means the initial condition of the subject is seen from its fatigue under the same conditions. After the activity, the mean of fatigue in period I was $60.72 \pm 0.52$ and the mean of fatigue at period II was $52.66 \pm 0.55$ with value $Z-3.901$ and $p$-value $=0.0001$. Thus it can be said fatigue after the activity is significantly different $(p<0.05)$ between period I and period II.

Fatigue experienced by crafters in Tangeb Village and Kapal Village before and after activity, both in period I and period II can be seen in Figure 2.

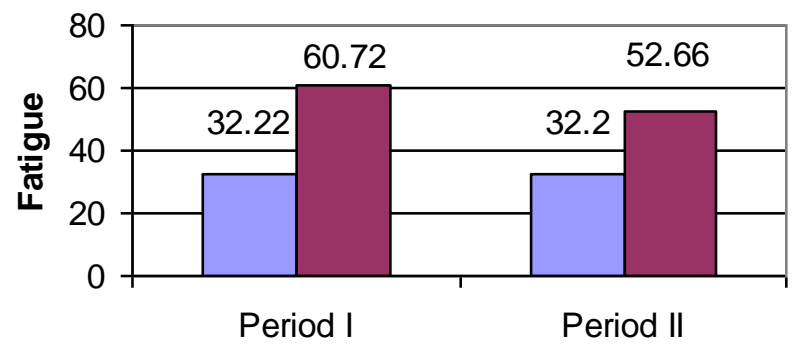

$\square$ Pre-activity $\square$ After Activity

Figure 2. Fatigue

\section{Conclusion}

Based on the previous discussion can be concluded that some of the essences of research can answer the existing problems, as follows.

Musculoskeletal disorders are pain that is felt in some parts of the body. The mean score of musculoskeletal disorders before activity in the period I and period II were $32.34 \pm 0.95$ and $32.22 \pm 0.87$ respectively, while the mean of musculoskeletal disorders after activity in period I and II were $54.61 \pm 3.56$ and $46.19 \pm 2.36$. The magnitude of the decrease in musculoskeletal disorders in the second period after activity was $15.42 \%$. The magnitude of musculoskeletal disorders in the first period is caused by the loading of the muscles especially on the wrist, waist, back, and buttocks as the craftsmen have to sit hunched over the floor, affecting the central nervous system and causing muscle fatigue. During work there is no rest and drink, it also adds too much muscle burden that causes muscle fatigue so that frequent stolen breaks to eliminate the fatigue.

After the activity, mean of fatigue in period I was $60.72 \pm 0.52$ and mean of fatigue in period II was $52.66 \pm$ 0.55 , or decreased $13.27 \%$ with value $\mathrm{Z}-3.901$ and $\mathrm{p}$-value $=0.0001$. Thus it can be said to be fatigue after the activity is significantly different $(\mathrm{p}<0.05)$ between period I and period II.

Widana, I. K., Sumetri, N. W., \& Sutapa, I. K. (2018). Effect of improvement on work attitudes and work environment on decreasing occupational pain. International Journal of Life Sciences, 2(3), 86-97. https://doi.org/10.29332/ijls.v2n3.209 
Acknowledgments

The authors would like to thank the Government of the Republic of Indonesia, especially the Bali State Polytechnic who has funded this research. The authors also thank the Head of P3M PNB who has helped facilitate the writing, implementation, and reporting of research. 


\section{References}

Alamgir, H., Li, O. W., Yu, S., Gorman, E., Fast, C., \& Kidd, C. (2009). Evaluation of ceiling lifts: transfer time, patient comfort and staff perceptions. Injury, 40(9), 987-992.

Borg, G. (1990). Psychophysical scaling with applications in physical work and the perception of exertion. Scandinavian journal of work, environment \& health, 55-58.

Bubb, H. (2006). A consideration of the nature of work and the consequences for the human-oriented design of production and products. Applied ergonomics, 37(4), 401-407.

Carrivick, P. J., Lee, A. H., \& Yau, K. K. (2002). Effectiveness of a participatory workplace risk assessment team in reducing the risk and severity of musculoskeletal injury. Journal of Occupational Health, 44(4), 221-225.

Caverley, N. (2005). Civil service resiliency and coping. International Journal of Public Sector Management, 18(5), 401-413.

Chaffin, D. B. (1974). Human strength capability and low-back pain. Journal of Occupational and Environmental Medicine, 16(4), 248-254.

Chan, A. D., \& Fishbein, J. (2009). A global engineer for the global community. The Journal of Policy Engagement, 1(2), 4-9.

Chandna, P., Deswal, S., \& Chandra, A. (2010). An anthropometric survey of industrial workers of the northern region of India. International Journal of Industrial and Systems Engineering, 6(1), 110-128.

Christensen, E. H., Hedman, R., \& Saltin, B. (1960). Intermittent and continuous running (A further contribution to the physiology of intermittent work.). Acta Physiologica Scandinavica, 50(3-4), 269-286.

Chung, M. K., \& Choi, K. (1997). Ergonomic analysis of musculoskeletal discomforts among conversational VDT operators. Computers \& industrial engineering, 33(3-4), 521-524.

Dul, J., \& Weerdmeester, B. (2003). Ergonomics for beginners: a quick reference guide. CRC press.

Dutta, T., Holliday, P. J., Gorski, S. M., Baharvandy, M. S., \& Fernie, G. R. (2012). A biomechanical assessment of floor and overhead lifts using one or two caregivers for patient transfers. Applied ergonomics, 43(3), 521531.

Epstein, Y., \& Moran, D. S. (2006). Thermal comfort and the heat stress indices. Industrial health, 44(3), 388398.

Erensal, Y. C., \& Albayrak, E. (2007). The impact of micro-and macroergonomics considerations on appropriate technology transfer decisions in developing countries: The case of Turkey. Human Factors and Ergonomics in Manufacturing \& Service Industries, 17(1), 1-19.

Gilad, I., \& Elnekave, M. (2013). Ergonomics improvements for the human operator-Cost effectiveness approach. Human Work Productivity: A Global Perspective, 1.

Grandjean, E. (1988). Fitting the Task to the Man, a textbook of Occupational Ergonomic.

Habibi, E., \& Soury, S. (2015). The effect of three ergonomics interventions on body posture and musculoskeletal disorders among stuff of Isfahan Province Gas Company. Journal of education and health promotion, 4.

Helander, M. (1995). A Guide to the Ergonomics of ManufacturingTaylor \& Francis.

Hignett, S., Wilson, J. R., \& Morris, W. (2005). Finding ergonomic solutions-participatory approaches. Occupational Medicine, 55(3), 200-207.

Hignett, S., Wilson, J. R., \& Morris, W. (2005). Finding ergonomic solutions-participatory approaches. Occupational Medicine, 55(3), 200-207.

McCann, M. (1996). Hazards in cottage industries in developing countries. American journal of industrial medicine, 30(2), 125-129.

Mitchell-Ketzes, S. (2003). Optimising business performance through innovative workplace strategies. Journal of Facilities Management, 2(3), 258-275.

Nishanth, R., Muthukumar, M. V., \& Arivanantham, A. (2015). Ergonomic workplace evaluation for assessing occupational risks in multistage pump assembly. International Journal of Computer Applications, 113(9).

Pandit, S., Kumar, P., \& Chakrabarti, D. (2013). Ergonomic problems prevalent in handloom units of North East India. International Journal of Scientific and Research Publications, 3(1), 1-7.

Parasuraman, A., Zeithaml, V. A., \& Berry, L. L. (1988). Servqual: A multiple-item scale for measuring consumer perc. Journal of retailing, 64(1), 12.

Pheasant, S. (1991). Ergonomics, work and health. Macmillan International Higher Education.

Widana, I. K., Sumetri, N. W., \& Sutapa, I. K. (2018). Effect of improvement on work attitudes and work environment on decreasing occupational pain. International Journal of Life Sciences, 2(3), 86-97. https://doi.org/10.29332/ijls.v2n3.209 
Sakurai, M., Orito, K., Tsukahara, N., Yamazaki, Y., Sakata, M., \& Yamamoto, S. (2012, April). Age-related changes of posture for pulling exercises in lower position. In Ergonomics in Asia: Development, Opportunities and Challenges: Proceedings of the 2nd East Asian Ergonomics Federation Symposium (EAEFS 2011), National Tsing Hua University, Hsinchu, Taiwan, 4-8 October 2011 (p. 67). CRC Press.

Widana, I. K. (2012). Redesigning tractors for reduced soil cultivation and increased productivity in the agricultural sector in Bali Indonesia. Ergonomics in Asia: Development, Opportunities, and Challenges, edited by Shih, YC., Liang, SF. M, 31-35.

Widana, I. K., Sumetri, N. W., \& Sutapa, I. K. (2018, January). Ergonomic Work Station Design to Improve Workload Quality and Productivity of the Craffsmen. In Journal of Physics: Conference Series (Vol. 953, No. 1, p. 012091). IOP Publishing. 


\section{Biography of Authors}

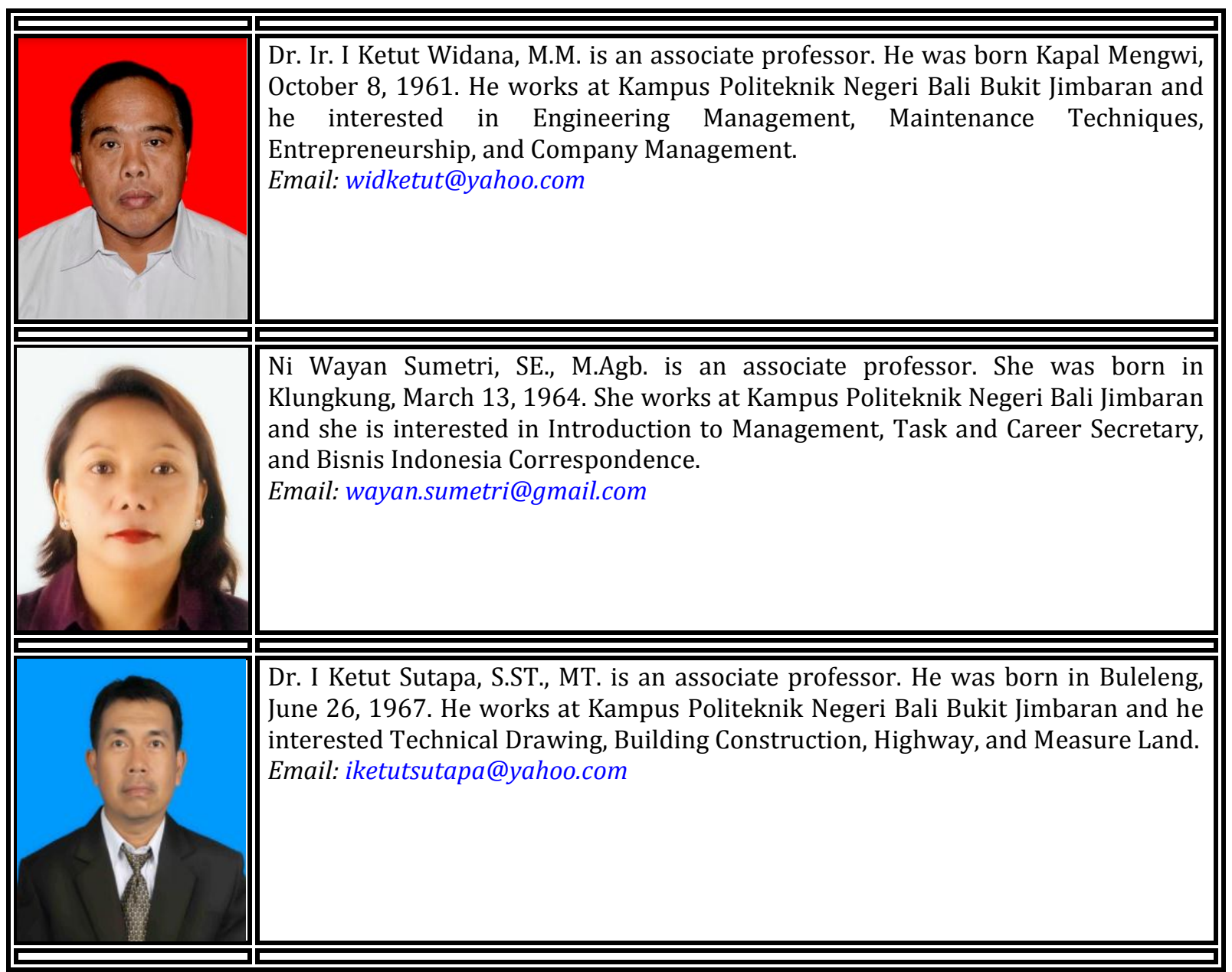

Widana, I. K., Sumetri, N. W., \& Sutapa, I. K. (2018). Effect of improvement on work attitudes and work environment on decreasing occupational pain. International Journal of Life Sciences, 2(3), 86-97. https://doi.org/10.29332/ijls.v2n3.209 